\title{
Some Features of Traditional Weaving in Vietnam
}

\author{
Doctor. Le Thi Hoa* \\ National Economics University, Hanoi, Vietnam
}

*Corresponding Author: Doctor. Le Thi Hoa, National Economics University, Hanoi, Vietnam

\begin{abstract}
Vietnam is a traditional agricultural country, associated with the traditional village, the traditional handicraft industry, from the past up to now it has always in an important role in socio-economic structure. In many traditional handicraft industries, traditional silk weaving in Vietnam has been well known in the world for its silk products. During the French colonial period, Van Phuc Silk was present at major exhibitions of colonial countries in Marseille (1928), Paris (1931-1938), Cambodia, Indonesia, Laos...... Today, traditional weaving is less the same but still plays an important role in the structure of import and export of Vietnam textile and apparel industry.
\end{abstract}

Key words: Traditional weaving, Silk, craft villages economic, handicrafts, villages.

\section{INTRODUTION}

Traditional weaving has a long history. In the records of feudal historians it has been evident from the post-independence era (10th century) that the silk carnation was very developed. By the middle of the eleventh century, silk had become an important economic sector for state income. The Ly dynasty was established the exchequer to oversee the production and taxation of silk as a manifestation of the strong development of silk weaving. Up to the Tran-Ho period, mulberry trees and silk weaving were closely associated with each Vietnamese family as an integral part of the agrarian economy. The old record says "every year the mulberry grows for silkworm rearing, each household has three hectares." King Le has three times promoted for agricultural production and silkworm cultivation for weaving in 1461,1485 , and 1498. A mandarin guard system was organized to the commune level to promote the farming land, silkworm cultivation, weaving silk. Planting mulberry and silkworm cultivation for weaving are also strongly encouraged by the Nguyen dynasty. In 1834, he released a motto: "advise the farmer to be hardworking able to have enough to eat, to take care of the silkworm cultivation in order to have enough to wear" (2). Thus, feudal dynasties attach great importance to the silkworm trade, by which the weaving industry has developed conditions leading to the birth of famous weaving centers throughout our country, including Van Phuc. Over time, weaving is growing. Originally from the traditional looms, traditional weaving techniques gradually developed from low to high, from primitive to sophisticated, from simple to complex, from the family occupation has become a professional village of weaving products for serving the upper class and export to foreign countries. Besides the improvement of looms, the process of creating patterns, searching for fibers combined with silk has created the diversity of traditional weaving products in Vietnam. In this article, the author will go more deeply about the silk weaving of Van Phuc village, now in the Van Phuc Ward, Ha Dong District, Hanoi is a well-known traditional silk weaving village with many products. It can be used at major trade fairs in the world.

\section{Method}

The author collects historical data on the economic and social situation of traditional handicraft villages in general and silk weaving in particular, relevant documents for research problems.

Survey and fielding some nearby handicraft villages that are influential and related to economic and social development of traditional handicraft villages, especially Van Phuc silk weaving villages and neighboring traditional weaving villages, the author has an overview of the evolution of weaving through the ages in history.

Research on the main issues of Vietnamese traditional silk weaving on the investment of French capitalists with traditional weaving traditions, which led to the shift of economic sectors in the 
traditional weaving industry, led to the transformation of economic and social stratification in craft villages

The author uses the method of historical materialism to study the formation, existence and development of the traditional silk weaving village. Based on the natural conditions, social history, culture, factors affecting the economic, social and cultural transformation of traditional silk weaving in Vietnam.

In order to solve the problems, the author uses the historical method, logical method and combination with different methods.

Historical methods, logical methods, comparative methods, survey methods, fieldwork, interview methods: Retrospective interviews and in-depth contemporary interviews. The subjects we interviewed were diversified in terms of economic conditions, social status, age, gender, etc. Especially we interviewed well-known artisans and village elders to understand clear history of custom, experience in production and life

On that basis, to clarify the outstanding features of the socio-economic transformation of traditional craft villages in order to clarify the role of the handicraft economy of the village, introducing traditional and characteristics of economic, sociality, politic, culture in order to further clarify the history of Vietnam's handicraft industry and at the present.

\section{Results}

Before the French colonial invasion, the silk industry in our country has developed strongly. In 1642, Alexandre de Rhodes was surprised at the production of silk and silk products in our country. So immediately after pacification our country, the French colonialists immediately thought of exploiting silk because it was "a matter of grave importance in terms of abundant technological and commercial resources in the North, because the production of fine silk will bring a great property, and chambers of commerce will increase prices compare to the present by 20 to 30\%" said Paul Bert, Governor of Central-North Area at the meeting of August 31, 1886 of the Central and North Research Committee for Agriculture, Industry and Trade. In order to better serve the exploitation of silk, France has established a Silk Sub-Committee. In the report of December 2, 1886, the Silk Subcommittee said: "The problem of silk in North plays the second most important role after rice, so you could find that there is less produce which is more worth considering and thinking than silks"(8). During the French colonial period, silk was encouraged for support. The silkworm in the first decade of the twentieth century was "strongly encouraged for support". In 1894, the Governor Delanessan issued a decree granting subsidies to silk producers. From 1905 to 1909, the French government exempted tax from silkworm cultivation, then set up model silkworm cultivation, and set up good silkworm farms to supply silk producer...

Why is there such a positive help? This is because during this time, the silkworm craft, the French silkworm, has difficulty in supplying silk to silk mills, so they have to promote silk worming in Vietnam to supply raw materials for factories in the country.

Silk worming, silk weaving can be said to have developed in history in many rural areas of Vietnam. After 1905 the French government took many measures to support and encourage the silk industry by exempting and reducing taxes. The French invested and established many silk quilting facilities from the North to the South such as Phu Lang Thuong (1905), Bach Hac (1914), Kien An (1916)... Since 1926, the French have spent 38.000 VND (piaster) to encourage silk worming, opened 3 models silkworm factories in Hue, Vinh, Binh Dinh. As can be seen in the French domination, the French have identified and soon seen the silk worming, silk weaving could develop and brought great benefits for French capitalists. French capitalists have actively invested capital and expanded production. Until 1923, the sum of money from the entire Indochinese budget for silk weaving in the North was 702.000 francs. In the Central was 123.000 francs. in the South was 129.000 Francs....With this source of capital, it has promoted the development of silk factories and companies throughout Vietnam such as Nam Dinh Silk Textile Joint Stock Conpany, Phu Phong (Binh Dinh), Tan Chau (Chau Doc), Dong Ich (Thai Binh)... It was clear that the French authorities really wanted to restore and develop the silk weaving industry in the hope of earning more for the French and some bourgeoisie in Vietnam. In 1926, the amount of silk exports was $68.000 \mathrm{~kg}$ of raw silk and $85.000 \mathrm{~kg}$ of wasted silk, worth 11.500.000 francs. In 1919, the value of the exported silk was only 4.237.000 francs. That meant almost three times the reduction. $80 \%$ of this silk was exported to France and $20 \%$ 
to Thailand (1). Looking at the export of silk from silkworm, from 1909 to 1929 this number proved a relatively good development.

Table1. Export silk

(Calculated by $\mathrm{Kg}$ )

\begin{tabular}{|l|l|l|l|l|}
\hline Year & South & North & Central & Vietnam \\
\hline $\mathbf{1 9 0 9}$ & 1.064 & 3.847 & 4.575 & 9.486 \\
\hline $\mathbf{1 9 1 0}$ & 724 & 4.255 & 6.008 & 10.987 \\
\hline $\mathbf{1 9 1 1}$ & 1.510 & 4.265 & 6.688 & 12.463 \\
\hline $\mathbf{1 9 1 2}$ & 6.439 & 1.741 & 9.407 & 17.577 \\
\hline $\mathbf{1 9 1 3}$ & 1.031 & 1.406 & 12.741 & 15.178 \\
\hline $\mathbf{1 9 2 9}$ & - & - & - & 39.400 \\
\hline
\end{tabular}

(Source: Cited follow Phan Gia Ben. (1995). Preliminary history of Vietnamese handicraft development, Publishers of literature, history and geography, p.15)

Export silk in 1929 increased more than two times, the highest in 1912. However, it was only export, not official production. Production numbers are unfortunately very rare, but if true, there is a significant increase in the production of silkworm and weaving. The number of silk types produced in 1918 is as follows (7).

Table2. The number of silk types produced in 1918

(Calculated by $\mathrm{Kg}$ )

\begin{tabular}{|c|c|c|c|c|}
\hline Type of silk & South & North & Central & Vietnam \\
\hline Fresh silkworm & 2.940 .000 & 1.800 .000 & 751.000 & 4.491 .000 \\
\hline Raw silkworm & 117.600 & 72.000 & 30.040 & 219.640 \\
\hline Rag & 147.000 & 90.000 & 37.550 & 274.550 \\
\hline Original silk & & & & \\
\hline
\end{tabular}

(Source: Cited follow Phan Gia Ben. (1995). Preliminary history of Vietnamese handicraft development, Publishers of literature, history and geography, p.11)

In general, in the period 1919-1930, silk weaving in Vietnam was maintained and developed despite the recession (1923 - 1924) caused by the competition for artificial silk, because the international market price is lower and because of the war. This profession was not actually demolished and the French government actually created good conditions for the maintenance and development of silk worming and weaving. Basically, this occupation is still widespread among the people, but a number of localities have been sub-techized, with few new machines and new improved technology. Some Vietnamese participate in this profession as bourgeois owners. These are new features of this historical period, and in terms of production, silk output has grown more than in the previous period.

For textile fabrics

The cultivation of cotton plant and weaving is a very popular traditional crafts in every villages. Historical periods have shown that French bourgeoisies have penetrated very early in cotton and weaving industry with companies such as Société Cotonniere du Tonkin, Société Cotonniere de Saigon, Delignon v .v... France wanted to gain dominance in this industry, so Dupré's Tonkin Cotton Group was granted exclusive rights to produce yarns in Indochina. French companies have exclusive rights to cotton and cotton textile, so Vietnamese textile factories have to rely on French companies for raw materials. Therefore, only the family at the countryside or villages in the specialized weaving can be possible to take advantage of the raw material through scattered cotton planting in all areas. In other words, cotton cultivation in rural Vietnam is sufficient for self-growers and for specialized weaving villages with close ties to rural areas. The textile manufacturers of the French bourgeoisies and a large bourgeoisie in Vietnam must use cotton fiber imported from abroad.

As for silk weaving, after the First World War was promoted more strongly. French colonialists in Indochina held fairs, exhibitions, examinations ... and awarded certificates of merit ... at the same time spreading the propaganda for the "revival of technology" of them. Due to this, weaving is encouraged because this profession only has to invest a little money, cheap labor to exploit the skillful skills workmanship so the profits are very high. A deep cause for France's support for the development of traditional villages is to make the villages "peaceful", not stand up against French domination, 
without the inexperienced and vulnerable; Hoang Trong Phu himself once remarked that "during the 1930s (all the traditional craft villages stand out for their peaceful character" (5). With such a goal, Hoang Trong Phu opened a local art handicraft school in Ha Dong and encouraged most of the province to promote handicraft, especially traditional crafts. The governor of Ha Dong Hoang Trong Phu then Vi Van Dinh (as the governor from 1938 to 1941) and son in law of Hoang Trong Phu named Ho Dac Diem (1941 - August 1945) selected some leading villages become "model village" and apply the policy "technology revival". Van Phuc Village is a traditional silk weaving village, located near the provincial capital, so it was quickly chosen and built into a model village.

Van Phuc textile village has long been popular with kings and people. "We met Mr. Do Van Ai, the grandson of Mr. Do Van Suu. Mr.Ai is just a normal craftsman in Van Phuc village. Poor and without property, he just had only a few tools used to weave was left by his grandfather at the bottom of a rotted box. Mr. Ai was given the necessary help to restore this precious technology" (4). In 1921, it was considered to be the year of renaissance of the weaving business in Van Phuc village. The village has two textile workshops going into production. One is directed by Mr. Do Van Ai, one is in charged by Mr. Nguyen Manh Khang with Van Phuc village

The achievements of the above mentioned need to mention the role of the governor Hoang Trong Phu in the "technology revival" in Ha Dong, Especially in Van Phuc weaving profession he was most interested. In his commentary on Ha Dong province, Ha Dong Trade Center has commented on the work of Hoang Trong Phu as follows: "By the development of handicrafts brought by him, facilitate the initiative, help with cash, often raising the individual's profit for the small capital that artisans need to practice their profession, he tightens his family relationship with benefits, making people busy working against the keeping one's hands in pockets situation. The economic prosperity of the province has helped the local head of this locality a lot in its political activities." (3)

Hoang Trong Phu actively encouraged the propagation of silk weaving in Van Phuc with French rulers, the Governor-General of Indochina, the governor of Tonkin and foreigners. He took them to visit the traditional weaving of Van Phuc. He suggested to the French Government and the government to grant certificates of merit and dignity to the skilled workers.

Hoang Trong Phu also asked the French Government to pay all expenses for Van Phuc to display the goods for sale at exhibitions inside and outside the country: Ha Dong Fair (1935), Auction in Hanoi, The Nam Vang fairs in Cambodia, Vientiane in Laos, Bolavia in Indonesia (1939), the Marseille exhibition (1928) in France, the French colonial handicrafts exhibition in Paris for the first time (1931), Paris for the second times (1938).

Hoang Trong Phu also built "Ha Dong Museum House" (later the Ha Tay Party Committee), including: a beautifully built saleshouse to display Ha Dong's handicrafts including silk, brocade of Van Phuc for selling, two blocks divided into many rooms to display the sophisticated crafts, where it is always produced and ordered on demand. Van Phuc alone is equipped with a weaving loom for customer to watch directly. The museum was inaugurated in 1925 . The weekdays, especially on Sunday foreign visitors to watch the technology of production and purchase is very crowded. Van Phuc's traditional weaving loom is very noticeable.

- The famous Silk Center, where the most famous textile weave at this time.

In order to serve the growing demand of the textile market in Van Phuc village, it is more open than the previous looms, which have been improved from the rudimentary frame, stomping legs, low productivity into yarn-pulling looms, $40 \mathrm{~cm}$ to $60 \mathrm{~cm}$ to silk sheet weave of $80 \mathrm{~cm}$. From the puller looms are replaced with loathes using the Zatka Hong Kong locomotive. As a result, productivity and quality increase. Productivity rises from 3 yards of medium size to 8 yard of large size in one day of a loom. From the 30s to before World War II, the number of looms in the village increased rapidly.

Table3. Development board of Number of looms in Van Phuc village

\begin{tabular}{|c|c|c|}
\hline Duration & Number of looms & Increase (compare to the previous) \\
\hline Before 1930 & 320 & \\
\hline From 1930 - 1935 & 500 & 1.56 times \\
\hline From 1936 - 1940 & 1500 & 3 times \\
\hline
\end{tabular}

(Source: Van Phuc Ward People's Committee) 
Within four years, from 1930 to 1935 , the number of looms increased from 320 looms to 500 looms, an increase of 180 looms, equivalent to $\approx 1.56$ times. Over the next five years (1936 - 1939), an increased more 1.000 looms, raising the total number of looms to 1.500 looms, increased three times. Compared with La Khe village (Ha Dong) - a village that in 1884 was King Thieu Tri the official fabric weaving silk for the State at this time there were only 600 to 700 weaving looms (6).

In addition to domestic sources, Van Phuc imported a large volume of silk from Britain, France, Japan, China ... annually consumes tens of tons of silk, the highest production of more than million meters of silk.

Van Phuc village was first weaving the, silk, later weaving, satin and silk weaving, the Van Phuc also used to make clothes to export to Paris. From 1935 to 1936 Van Phuc weaving more wicks. The item is more and more diversified. Men and women in the village from 16 years old and above all know weaving. The 13-year-old was able to weave the first silk. However, there are still 3.000 people from other localities coming to learn and work with 3.000 Van Phuc people every year.

Van Phuc silk started to compete with the world market, opening up a new possibility for the village's textile industry. In the feudal period, Van Phuc silk textiles were mostly sold or exchanged at the village's Dinh market. As the textile industry grows, silk is sold in Do Market (Ha Dong) - a regional market. In the French colonial period, capitalist elements entered the market in a step by step, breaking the narrow trading boundaries of a regional nature. At that time, the goods were sold at Hang Ngang, Hang Dao (Hanoi). Since then, Dinh market and Ha Dong market is no longer the place to trade silk as bustling as before, Van Phuc textile products mainly sold in Hanoi. The mode of exchange is conducted in the family unit. The market schedule is as follows:

Table4. The regional market schedule

\begin{tabular}{|c|c|}
\hline Markets & Market Day (lunar calendar) \\
\hline Hang Ngang, Hang Dao (Hanoi) & 1,6 \\
\hline Do Market & 5,10 \\
\hline Dinh Martket & 2,7 \\
\hline
\end{tabular}

(Source: Van Phuc Ward People's Committee)

In addition to the form of selling in each family is common also in the form of several families linked together to sell goods. This form appeared in the 30s of the twentieth century due to the fact that capital goods developed strongly, which made some small-sized owners in Van Phuc have a lot of capital and a large volume of textiles, together, they started selling bases for the launch of "Phuc Hop Shop" and then "Long Van Company".

Phuc Hop Shop was established in 1930 - 1931, based on ten households in Van Phuc village with many looms (5-7 looms) linked together for sale in Hanoi. With a large number of items, the products are diverse: ribbons, tapes, cinnamon, silk, sa ... so their goods are easier to sell and more expensive than those who doing retail. In the evening, when they return, they devided the turnover amount. The prestige of this family group is increasing, there are many merchants ordering. At this time they do not go to Hanoi anymore but their customers from many place came to Van Phuc to purchase (Hanoi, Hai Phong, Saigon ...) For convenience of trading, they opened the shop right at the village named Phuc Hop Shop. Sourcing for the initial sale was weaved by these families. Later on, due to the demand in volume of goods they bought more in Ha Dong market and in the village. There were guests at Saigon demanding "Phuc Hop" transport products to there. A trading agent named Long Van Company of Phuc Hop Shop was born at No. 229 Lagrange Street (behind Ba Den Pagoda) Saigon

After a period of strong development (1930-1939), until the Second World War broke out, the import and export of French goods was limited, silk weaving began to encounter difficulties. Source of raw materials and consumption of products is weak, weaving industry tend to go down. By 1945, the August Revolution was successful, opening a new stage of development for the textile industry.

\section{DISCUSSION AND CONCLUSION}

Although many traditional villages have disappeared with time, nowadays statistics show that Vietnam has nearly 2.000 trade villages of the main occupations: lacquer, ceramics, gold, silver, embroidery, paper, stone wood.... In the silkworm and silk weaving industry have always played an important role in the level of traditional handicrafts competition in Vietnam through historical routes. 
Today, before the integration period, silk weaving has opened up new opportunities for development, but facing many challenges before the impact of the goods applied modern science and technology. The traditional silk weaving industry in Vietnam has benefited from the competition in the context of major agreements such as AFTA (ASEAN Free Trade Area) as a multilateral free trade agreement among ASEAN countries in the spirit of the agreement, the tariff reduction will be reduced to $0-5 \%$, gradual elimination of tariff barriers for the majority of commodity groups and harmonization of customs procedures between such countries so that the goods of Vietnam in general and traditional textiles in particular will have many opportunities to target large markets in the region.

In particular, the TPP Agreement (Trans-Pacific Strategic Partnership Agreement) with the elimination of tariff barriers for tariff lines for Vietnamese textiles and clothing, the agreement, when put into effect, will create conditions for these products to penetrate the large market, integrate into the world economy, contribute significantly to the import-export turnover for Vietnam, generate revenue The textile and garment development solves many problems of employment, cheap labor in the Vietnamese market.

In the conference "Trans-Pacific Strategic Partnership Agreement (TPP) and impact on Vietnamese garment enterprises" was held in Dong Nai by the Vietnam Textile Association and Dong Nai People's Committee. There are many opinions of experts that the advantages of the TPP is the wide freedom of goods and import duties are eliminated completely when the Agreement is in effect.

Textile and garment exports to the US market, the tax rate of $17.5 \%$ in the European market the tax rate is $9.6 \%$ in case the output of textile and garment of Vietnam to this market accounts for less than $17 \%$, if Export turnover exceeds $17 \%$, the tax rate will automatically adjust to $17.5 \%$ the same as the US market.

Vietnam Textile and Garment Association said that the textile and garment industry is currently conducting surveys on six areas including market, materials, labor, equipment, management and finance of domestic textiles and garments enterprises, to have detailed aggregate data to further participate in negotiations on the TPP integration process.

Nguyen Van Tuan, Deputy General Secretary of the Vietnam Textile and Garment Association, said that the export turnover of the textile and garment industry is now ranked second in the total export turnover of the whole country.

If the textile and garment export turnover in 2011 reached nearly 2 billion USD, the turnover in 2012 have reached 17.1 billion USD, making Vietnam became the fifth largest textile and garment exporter in the world.

However, Mr. Tuan also said that the major challenge of Vietnam's textile and garment industry is the dependence on foreign materials, backward technology equipment, much dependence on processing.

Some raw materials such as cotton must be imported $99 \%$ from the countries' market; fabric must be imported from 6 billion meters on the total demand is 6.8 billion meters; Fiber material must be imported 50\%.

According to the Vietnam Textile and Garment Association, the tariffs for key export markets of Vietnam are too high. Specifically, in the US textile and garment export market, the US accounts for $50 \%$, Europe accounts for 17\%, Japan 12\%, South Korea 6\%, and accounts for 2\% for the rest other markets. In particular, the US market is subject to a tax rate of $17.5 \%$ and Europe is $9.6 \%$.

Mr. Nguyen Van Tuan analysis, if after Vietnam signed the TPP Agreement, the export tax rate of textile and garment products in the United States and markets of TPP countries will be lifted.

On the other hand, through the TPP Agreement, Vietnam will have the opportunity to negotiate for the United States and its member countries to open markets for Vietnamese goods, creating strong leverage to the development of export and curb trade deficits.

In theory, any country has state-owned enterprises, just different in size and field of activity. Many people say that the provisions on state-owned enterprises are aimed at Vietnam and Malaysia, the two countries have regional and world-class state-owned enterprises, playing an important role in the economy. Malaysia's constitution provides more favorable conditions for economic activities involving indigenous peoples, which create many difficult to negotiate the economy. Vietnam has 
long been emboldened by state-owned enterprises to take advantage of bank loans, using resources such as land and a number of monopoly sectors. In this regard, Vietnam's chief negotiator, Deputy Minister of the Ministry of Industry and Trade, Mr. Tran Quoc Khanh said that when joining the WTO, we have firm commitments on state-owned enterprises. The TPP commitments remain fully aligned with the reform roadmap for transparency in state-owned enterprises in line with the Party's and State guidelines and guidelines.

In particular, we need to take note on the problem of the principle of origin of goods in the TPP: Only items using raw materials within the TPP are entitled to a preferential tax rate of $0 \%$. The regulation will strike directly in Vietnam's key export sector is textile and garment.

So far we have relied on cheap labor to compete in the textile and garment market. The auxiliary industries are almost abandoned to the fact that materials from China are flooding the Vietnamese market with this situation, the textile and garment industry - and possibly many other industries - will not be entitled to benefit from the TPP Agreement. As we are still struggling, many Chinese and Taiwanese businesses have quickly invested in Vietnam, investing in textile auxiliaries, doubling the investment of China compare with 2012. From that, Chinese businesses will most benefit from the commitments of Vietnam, while Vietnamese businesses must outsource for surface profits.

We do not accept a higher principle of origin for tariff preferences, so in the short term, Vietnamese enterprises will entitled to benefit, even if that benefits are not worth much compared with foreign companies holding $98 \%$ of the market share of raw materials. This is a chance, a motivation for businesses to change their thinking in a comprehensive manner so as not to be eliminated right in the country. In the textile industry, the textile industry requires huge capital and most polluting. We have to carefully consider trade-offs to take advantage of this opportunity.

The issues mentioned above are only a small part of the challenges and opportunities that TPP will bring to Vietnam's textile and garment industry. In the long term, the strategic agreement of the century will push Vietnam to make strong changes and reforms in a better direction. In addition to having to compete with "strong" foreign competitors in many areas, we will have access to a whole new generation of technology, machinery and materials are huge capital flows into the economy after the signing of the agreement. The handicraft items in general and traditional crafts in particular face many opportunities and face many challenges in the process of integration.

Some recommended solutions to preserve and develop traditional weaving in the integration process

It is necessary to promote the role of the subject, ready to prepare for the integration of traditional craft villages in general and textile and garment in particular; must always take the initiative in the process of integration by promoting nimble dynamism and willingness to compete with major countries. The craftsman must constantly make effort and creativity from the change of technology and techniques to produce high quality products but still retain the traditional elements and meet the tastes of the current market.

It is necessary to have policy support from state management agencies, mass organizations and social organizations to preserve and develop traditional craft villages by finding stable output for products of traditional handicraft weaving, production capital support, production expansion of a larger scope.

The mass organizations should pay attention to the propaganda and education to raise the awareness of the community in protecting and promoting the village traditions, enhancing funding for the cultural and historical relics of the village. Need to introduce the culture and products of the trade village by building up brands, there is a gallery showcasing the famous products of artisans. There should be a mechanism to encourage skilled artisans by giving and rewarding merit.

It is necessary to associate craft villages with tourism development and services such as the preservation of historical and cultural relics, traditional cultural space, promoting the branding of traditional craft villages to localities in the country as well as in the world.

It can be said that the preservation and development of traditional craft villages in the current context have many opportunities and challenges in the process of competition with industrial goods in the period of industrialization and modernization. Along with a number of solutions in general, the State needs a lot of supportive policies to promote handicraft villages by giving priority to loans, tax incentives.....Production space is also a difficulty that traditional villages want to expand the scale of 
production is encountering. Therefore, the State should have mechanisms and policies to allocate land and contracts to lease land in a stable manner so that production establishments in traditional craft villages can expand production scale. It is necessary to create conditions for traditional craft villages to have access to information on technology, science and technology and markets; to support capital and create conditions for trade villages to participate in fairs, exhibitions, seminars ... so that they can access information actively in the process of integration

\section{REFERENCES}

[1] Based on Indochina Morn. Indochina Morn, p774.

[2] Chronicle of Greater Vietnam. (1965, Book 15). History Association Publishing house, DC: Author.

[3] Ha Dong embassy. (January 14, 1933). Comment on Ha Dong province, Le Gia Hoi, code DC19/NH121, p.24.

[4] Hoang Trong Phu. Family Technologies in Ha Dong, Sign language translation: Add.47/C.101N, Ha Tay library, p.7.

[5] Hoang Trong Phu. Family Technologies in Ha Dong, Translation Code: DC.47/C.101N, Ha Tay library, p.180.

[6] Lam Ba Nam. (1999). Traditional weaving in the Northern Delta of Vietnam, Social Science Publishing House, p.124.

[7] Literature-History-Geography Publishing House. (1995). Quoted in Preliminary history of the development of handicraft industry in Vietnam. Indochina Economic Journal, No.138, p.115.

[8] Phan Gia Ben. (1995). Preliminary history of the development of handicraft industry in Vietnam. Literature-History-Geography Publishing House, p.11.

\section{AUTHOR'S BIOGRAPHY}

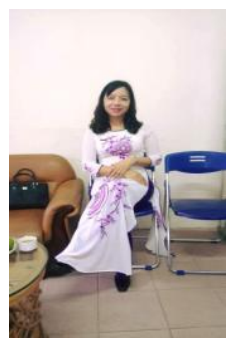

Dr. Le Thi Hoa, born in 1978. I am a lecturer at National Economics University, Vietnam. I specialize in teaching and researching on social sciences, socio-economic issues.

Office address: Dr. Le Thi Hoa, Department of Political Theory, National Economics University No. 207 Giai Phong Street, Hanoi capital, Vietnam.

Citation: Doctor. Le Thi Hoa. "Some Features of Traditional Weaving in Vietnam" International Journal of Humanities Social Sciences and Education (IJHSSE), vol 8, no. 4, 2021, pp. 210-217. doi: https://doi.org/10.20431/2349-0381.0804017.

Copyright: () 2021 Authors. This is an open-access article distributed under the terms of the Creative Commons Attribution License, which permits unrestricted use, distribution, and reproduction in any medium, provided the original author and source are credited. 